\title{
An Inextricable Link of Nature, Culture, and Education: An Overview in Nepal
}

\author{
Gem Prasad Gurung ${ }^{1} \&$ Suman Kumar Shrestha ${ }^{1}$ \\ ${ }^{1}$ Tribhuvan University, Sanothimi Campus, Bhaktapur, Nepal \\ Correspondence: Gem Prasad Gurung, Tribhuvan University, Sanothimi Campus, Bhaktapur, Nepal.
}

Received: February 14, 2021

Accepted: March 25, 2021

Online Published: March 30, 2021

doi:10.5539/mas.v15n2p88

URL: https://doi.org/10.5539/mas.v15n2p88

\begin{abstract}
Nature, culture, and education are interrelated to each other to maintain the beauty, peace, and habitability of the earth planet for all living creatures. But it's being a hidden subject in concerned authorities. Nepal is rich in natural biodiversity as well as cultural diversity. Education is the main medium to handover the (cultural) knowledge of nature conservation to their generation. Hence this study aims to explore the deep relationship between nature (environment), culture, and education.

As per the nature of research objectives, qualitative research methodology has been adopted. The reviewed literature is related to the world's perspectives and practices to maintain interrelation among nature, culture, and education. Hence, this study can contribute to making people aware of environmental conservation by exploring the relationship of our nature, human culture, and education. From the study, all the concerned environmental justice communities, agencies, and institutions would endeavour to link their particular significant roles for nature conservation.
\end{abstract}

Keywords: biodiversity, eco-centrism, environment conservation, homo-centrism, informal education, indigenous people, natural heritage, sustainable use

\section{Introduction}

The study is to explore how nature (environment) is interrelated to human culture and education. Human culture and education play a vital role to minimise the degraded environment in the local community as well as in the world. It is studied in a particular ethnic community of Nepal. The study is proceeding on introduction, background, study of related works of literature, methodology, findings and discussion, conclusion and lastly managed references. As the nature of objectives it is adopted qualitative research design.

\subsection{Background}

Nature and human culture are inseparable in the world. Humans depend for their livelihood, on natural resources/environmental resources. They depend directly or indirectly on these resources (Adhikari \& Ghimire, 2003). The mode of using natural resources depends on their interest, society, culture and technology, and economic condition. Therefore, the use of ecological benefits is not distributed equally which is causing conflict in the world/society (Adhikari \& Ghimire, 2003).

The powerful countries are consuming the resources haphazardly. They are consuming natural resources i.e., forest, fuels, water, and land for their developmental activities. Hence, is ultimately causing the degradation of biodiversity thereby environmental pollution. As the result, global warming, the greenhouse effect, ozone layer depletion, and climate change, etc. have resulted. Similarly, the condition of the living beings in nature has become critical. Environmentalists and scientists have also raised voices to preserve nature. Consequently, different national and international conferences are held to address this global issue such as Stockholm Conference in 1972, The Earth Summit held in Rio de Janeiro, Brazil in 1992, etc. Likewise, various national and international environmental agencies are also working for nature conservation (Karki, 2000).

For the support of the above activities, different studies (Gurung, 2018; Konsa, 2016; Stoffle, Toupal, \& Zedeno, 2003) observe that human culture also plays an important role in nature/environment conservation. Turner, Geertz, and Levi-Straus (cited in Gurung, 1996) also opine that humans maintain the natural environment through their culture. Regarding the authors' views, nature is conserved through their cultural perception and symbolic system (Gurung, 1996). 
Obomsawin (1993) also reported that culture is seen in prevalent human attitudes, behaviours, and relationship with humans' surroundings (nature). Hence, it is considered that culture is the unique value of the way of life with all the phenomena that distinguish a particular community or society. Moreover, culture determines the ultimate forms of development i.e., their social organization, religion, ceremonies, and local institutions, aesthetics, education, technologies, and structures. Therefore, culture can minimize or bring in more or less relief to the degraded environment.

Another fact is that education is the key factor to bring in knowledge to humans either in a formal or non-formal way. Khatri (2005) also opined that sustainable development and the happiness of the country depend upon quality education. In addition to this, it should be effective and helpful in the conservation of natural heritage and biological diversity. According to Hesselink and Cerovsky (n.d), education is a weapon that can motivate and empower humans to support environmental conservation, not only by supporting lifestyle changes but also through promoting the thinking on cultural and spiritual values of nature conservation.

Khatri (2005) also added that education meets interlink with all the knowledge, policies, and practices existing in the society. Education involves the change of behaviour through deliberating knowledge. Therefore, it is called the means of people's enlightenment and the boost of knowledge. Environment education, which is approved by the International Union for the Conservation of Nature (IUCN) and the then His Majesty's Government of Nepal $(\mathrm{HMG} / \mathrm{N})$ implemented in formal education is effective for positive changes in the conservation concerns all over the country (Khatri, 2005).

Non-formal education also plays a strong role to make people aware of environmental conservation. Sources of non-formal education such as radio, television, news, and journals, etc. also contribute to add knowledge and skills for sustainable nature conservation. Skanavis and Petreniti, (2006) also said "non-formal education is the major way of spreading the environmental information to the public through recreational and educational purpose" (pp. 1-7).

Informal education also plays an important role in handover traditional knowledge. It carries cultural knowledge and practice and belief system of nature conservation such as worship of natural resources, well management of those resources through elders' livelihood phenomena. Hesselink and Cerovsky (n.d) state, "Informal education is the process whereby every individual acquires attitudes, values, skills, and knowledge from daily experiences, such as family, friends peers and media" (p. 1).

Regarding the authors, informal education promotes the cultural norms and values of people concerning natural resource preservation such as the Maori culture of New Zealand in which nature is worshipped. Likewise Hindu culture respects and worships the river, plants, etc. The indigenous people of Nepal preserve plants on their grave land, make the resting place and plant bar (Ficus benghalencis) peepal (F. religiosa) and dig a pond near the resting place (Gurung, 2018). Buddhist culture believes in nonviolence, which restricts the destruction of any animals and plants.

Therefore, culture and education are equally important for nature conservation. If nature is beautiful, peace and perfect then it will be suitable to dwell all the living creatures as well as human beings in the world. Likewise, if there is (balanced) development of natural heritage, it will be considered as the success of environmental education or it seems to have achieved the goal of environmental education. Therefore, the following objectives are adopted in the study:

-to explore the interrelation of nature, culture, and education in Nepal,

-to raise awareness to preserve nature and culture through effective environmental education.

\subsection{Nature and Culture Theory}

The dichotomy of humanity (culture) and nature (the environment) is an important characteristic of the Western worldviews. But in contrast, Eastern worldviews are based on monism and believe that people and environment are two different expressions of the same entity (Rainisio \& Inghilleri, 2013). The authors observe more, the Western culture has supported a vision based on a determinist relationship between nature and culture despite a change in other considerations according to the theories of reference, while the Eastern one has preferred bidirectionality and mutual interdependence.

In this regard a UNESCO report (2007) also explores the inseparable relation of nature and culture;

The notion of the inextricable link implies not only that biological and cultural diversity are linked to a wide range of human-nature interactions, but also they are co-evolved, interdependent, and mutually reinforcing. Each culture possesses its own set of representations, knowledge, and cultural practices which depend upon 
specific elements of biodiversity for their continued existence and expression. The cultural group develops and maintains significant elements of biological diversity, with knowledge and practice as the media for their management. (p. 7)

As the consideration of this study, Rainisio and Inghilleri (2013) view that cultures are supposed to be a framework for different representations of nature. Hence to preserve, restore and save our nature is the main theme in contemporary society and study. Psychological and physical science too is involved in developing strategies to implement a virtuous circle of pleasant environments and quality of human life.

\section{Study of Related Literature}

A literature review promotes to study of relevant documents of the research topic. It helps to get more information and find out the gap in the study area (Creswell, 2012). The literature review not only guides the researcher to collect a heap of documents but also initiates critical review and triangulation of related subject matter with field data. The review of literature is managed into two themes in this section.

\subsection{World Culture and Nature Conservation}

The concern for nature conservation is deeply embedded in different cultures. Culture is the patterned behaviours that a social group develops to understand the society and survive its environment. Therefore, culture is shaped by human and natural forces which encompass knowledge, ideas, norms, and values of the community and transmitted consciously and unintentionally across the generations (Goucher, LeGuin, \& Walton, 1998).

Maori mythology holds that all life forms come from the sky and the earth and humans are related to the mountains. For the Maoris, the mountains are sacred, and traveling into them was forbidden. Also, it is said that long ago travellers wore special hats to prevent them from seeing the mountains (Hadley \& Hay-Edie, 1998).

Likewise, the Hani culture of China has enhanced the understanding of forests and socialized the processes. For instance, in the Hani community when a baby is born, the parents plant three young trees at the foot of the village and the placenta is buried under the trees. Also are watered with the water used to wash the baby. The trees grow as the baby grows as they care for them simultaneously. When there are more children, more trees are planted then it becomes a forest. This cultural practice strongly emphasizes the relationship between humans and nature (Qinghua, 2004).

Then, the researchers studied a Japanese culture. In Japan people plant trees on the graveyard. The concept of planting a tree on the burial ground has also become popular among professionals of the funeral industry in Tokyo (Penmellen, 2014). This contributes to the development of ecology in nature.

In India, nature worship has been a key force in shaping the attitudes of humans towards sustainable use and preservation of natural resources. The customary practice of nature worship in different parts of India promotes the national and regional goals for the conservation of nature. This shows the communal belief systems governing values and the linkage between humans and the natural world. They conserve sacred groves as the symbol of the natural god. According to the mythology and historical scriptures, as spiritual guides, sacred forests are the ruler of the land. Therefore, the tradition of nature worship emphasizes two forms i.e., primarily ethical, intrinsic, non-use, and indirect values of biodiversity and secondarily for direct or consumptive values (Sexena, Rao, \& Maikhuri, 1998).

In the Americans, a widespread view in pre-Columbian times was that Earth and all other creatures are sacred. Trees were seen as having spirits and the powers to help or hurt. So, their permission should be taken before their use of any parts (Hughes \& Chandran, 1998). In the light of this universal sacredness, problem is to determine the specific groves in America. Hughes and Sawn (cited in Hughes \& Chandran, 1998) argue "Still the native people believed that although the whole Earth is sacred, still in certain places the spirit power manifests itself more clearly and readily 'like a fawnskin' with its many white spots" (p. 77).

At the beginning of Africa, the original home of humankind was a sacred grove that is still in existence in almost every sub-Saharan section of the continent. In the Kikuyu community of East Africa, they are restricted to cut any tree or break the branch, gather firewood, fire on the grass, and destroying wild animals that have taken refuge in the groves. In West Africa, an aura ceremony has proclaimed botanically rich groves to protect from falling the trees by a lumber of companies. Sacred groves still exist in Ghana. In Northern Ghana, the Malshegu community has preserved a small forest that they believe the house of a local spirit. Although that is threatened by various human developmental activities, the grove is protected by strong traditional, religious beliefs of the community. Likewise, almost all the African countries have beliefs and the conservation of sacred groves (Hughes \& Chandran, 1998). 
In Sri Lankan culture, the forest was considered a place of peace and healing. When monks got restive and difficult, Buddha had said to lead them to a forest in the Himalayas then they get peace from the beauty and calm of the forest. The Buddhist religion of Sri Lanka plays a great part in the traditional and cultural practices of the country. They believe Gods are generally good, beautiful, kind and they inhabit the selected trees i.e., Nuga (Ficus sps.), Bo (F. religiosa), Ahala (Cassia fistula), etc. However, they are known to get angry if the trees are harmed. Then these trees should not be touched, unless essential (Withanage, 1998). It is also found that in rural areas of dry zone people of Sri Lanka, people still respect the natural elements such as forests, trees along with gods, and other deities. Thus, the culture certainly helps to conserve nature.

\subsection{Education for Nature and Culture Preservation}

In a sociological aspect, education is a socialization process for the transmission of society's values and moral rules (Giddens, 2009). Similarly, it is also the learning process through instruction, and experience in the learning environment. Aggarwal (2002) also states that education transmits the culture of one generation into another.

According to Khatri (2005), education enlightens the mind and heart of the pupil that brings behavioural changes. He adds more;

Education for sustainable development brings a context and motivation to learning. Young people take care of their future and the type of world they live in. Education for sustainable development can help pupils to develop the understandings, skills, and values to contribute in a positive way, which enhances self-respect and increase motivation. (p. 321)

To preserve the environment, different educational international Conferences are held in different periods. For example, Stockholm Conference was held in 1992 where 133 nations attended the conference entitled the 'Human environment'. The Major objective of this conference was to initiate the programs of environmental education. It emphasized the condition of the environment which is damaged by the activities of human beings. The conference stressed preserving the environment to develop a positive relationship between human beings and nature (Karki, 2000). Likewise, different Conferences like Belgrade Conference in 1975, Tbilisi Conference in 1977, and the following different Conferences come to Earth Summit Conference held in Rio de Janeiro, Brazil in 1992. All the Conferences were focused on the development and implementation of environmental education effectively in the world. Different pieces of training, curriculum development, workshops were held for the effective implementation of environmental education. With regards to Khatri (2005), the collaborative effort of IUCN and HMG/N has prepared a curriculum previously and implemented it at the secondary level. Now, all the level of education has incorporated environmental education as an academic subject. The study of environmental science in own department in Universities is the best example of formal education in Nepal.

Non-formal education can also play a strong role in nature conservation. Radio, television, magazines, newspapers can raise people's awareness of the sustainable management of natural resources in the community. This is the programme to meet any aims out of a structured classroom. In this regard, Hesselink, and Cerovsky (n.d) state that the educational activities which are organized outside the established formal system of the educational institution are called non-formal education. Likewise, Karki (2000) also observed that both formal and non-formal education systems can change people's attitudes, values, behaviours, knowledge, and skills for nature conservation.

Likewise, informal education also has equal importance in preserving natural resources through customary rules of their management. Indigenous people have their ritual practices to respect and manipulate natural resources. They are transferring their cultural and traditional knowledge regarding nature conservation to their young generations as their livelihood experience such as worship of forest, trees, water, stone, etc. as their natural god. Supporting this, Hesselink and Cerovsky (n.d) opine that informal education is a process by which people can learn attitudes, values, and knowledge from daily experiences, such as family, friends, peers, and elders.

\section{Methodology}

This study employed qualitative research design as the nature of objectives (research questions). As per research philosophical premises, the study followed ontology, epistemology, and axiology (Denzin \& Lincoln, 2005). Regarding this, it would find out different communities' existing reality, the source of knowledge, and the value of their thinking. The researchers have selected Kaski district for the study field because the rural communities of that district are following their cultural norms and values for management of natural resources. Moreover, twelve informants, such as village leaders, priests, students, and teachers were selected purposively for the study. The purposive sampling procedure was used because it would help to collect information as required for research questions (Flick, 2010). In addition to this, snowball sampling was also followed when necessary. For this study, 
data collection techniques were in-depth interviews and field observation. The information was collected with the help of the interview protocol and observation checklist. Analysis and findings were concluded following the grounded theory approach (Denzin \& Lincoln, 2005; 24). Collected text data were refined through coding and decoding within transcribed text data (Patton, 2002). For the trustworthiness of the study, it was done peer checking and prolonged study as the norms of qualitative research. Ethical consideration was followed since we never imposed to provide information in oppose to their interest of the informants (Trochim, n.d).

\section{Findings and Discussion}

\subsection{Harmonious Relationship of Nature and Human Culture}

Nepal is a country of a multicultural, multi-religious, multiethnic, and multilingual community (Bhattachan, 2008). As their diversity of culture, they have various worldviews, knowledge, and practice in natural resource management. In the study, Hindu culture (Brahmin community), had a very close relationship with the environment. An informant of the community said they respect and worship the natural elements like different flora and fauna in the earth. Mainly they plant tulsi (Ocimum sanctum) in the yard and worship daily as the symbolic form of Brahma, Vishnu, Mahesh, and other gods (Bhalla, 2007). Hindu culture believes in Brahma and is regarded as the creator of the universe. So, they take care of all the creation of Brahma i.e., all the natural elements in this world.

Likewise, Brahmans respect and worship water, river, sun, moon, air, soil, etc. They also have the practice of planting Bar and Peepal at the resting place. As the informant reported that in the Brahmin community, they also respect animals linking them with their deities like the lion to Durga, bull to Shiva, monkey to Ram, etc. Among birds, they believe the swan as Brahma, eagle as Vishnu, peacock as Saraswati, etc. Trees are planted in the compound of temples. Therefore, Hindu culture always keeps in regards and well management of all the natural resources.

Gurung is an indigenous community of Nepal (Bhattachan, 2008). They have unique culture and tradition like the other ethnic community in Nepal. Gurungs are nature worshipers in practice. An informant of the Gurung community explores that their life is inter liked with natural resources from birth to death. During probing the question he added;

We use dubo (herb) pati at the nwaran of new baby. Kachhi (a kind of plant) at chhewar (first hair cutting), and chhikuta (a kind of plant) at death rituals. Many more plants like bamboo, nigalo, amriso, etc. come into use in different puja as well as other life activities. Asala machha (fish), milk, banana leaf, etc. are essential at the last function of the marriage (dhogbhet phukaune) ceremony. Bamboo, nigalo, kachhi, chhikuta are necessary for the death ritual.

(Personal communication, 2069 B.S)

They not only use those ritual plants but also preserve them in their surroundings. According to the informants' report, the researchers observed that they have a culture of conserving vegetation at their graveyard. It is restricted to fetch any resources from the areas. Gurungs have norms and values of keeping greenery in their grave land.

As their cultural practice, they worship water resources, forests, hills, dens, trees. They also believe in supernatural power, thus, they respect and worship their ancestral spirits and territorial god/goddesses. Udhouli and ubhouli puja are held as their seasonal puja for nature on the wishes of good weather and good climate for their crops as well as villager's daily life.

Gurungs also follow Buddhism, so they believe in and practice non-violence. They have norms and values to stop destroying the flora and fauna of their territory. They have twelve $l H o$ (barga) systems in the birth. The $l H o$ chakra is indicated by twelve animals in each such as cow, rat, deer, dog, bird, monkey, sheep, horse, snake, eagle, cat, and tiger. So, they have a cultural relationship with those flora and fauna.

Tamang community of Nepal has also great efforts to conserve nature. They are also Buddhist and animist (bon) followers (Siwakoti, 2009). Tamangs use and conserve different plant resources in their culture which help to keep harmonious relation with nature. According to informants, they use flower of totelo (Oroxylum indicum L.), titepati (Artemisia vulgaris L.) on the occasion of the purification programme of their new baby. They also have norms and values to respect and preserve natural resources like stones, rocks, mountains, caves, rivers, and forests, etc. Around sacred places, people do not pollute and collect the resources they like. Their cultural behaviours show that a strong interrelation with nature and culture. They also consider the value of birds, snakes, and other animals. According to field information, the Tamang community conserve and respect Bodhi Chitta Mala (sacred beads) (Ziziphus buddhensis) to believe in enlightenment in the heart and mind. The belief is not only in the local community but also in the global context. 
As per the words of the Tamang elder person, they are conserving community forest performing Banjhankari puja and other pujas like Chandeswori Mai, and Nag puja, etc. They also follow Government rules and regulations for community forest conservation. So, it can be said that they intermix the customary knowledge and modern knowledge for natural resource management.

One of the informants said, at their death ritual they use bar, peepal, mango leaf, champ, paiyu, Dhupi, nigalo, tatelo, and titepati, etc. So, they preserve them in their surroundings for their cultural use. In this regards, Lama (2010) states:

Tamang's knowledge and socio-cultural norms, rules, and regulations of forest management and conservation have been developed since a long ago and handed over from generation to generation. The way of thinking and perceiving the environment is a fundamental element of their subsistence. (p. 96)

In the case of nature conservation, we cannot demark the culture and beliefs in Nepal. Due to the acculturation, non-Hindus follow Hindus practice like worshiping cow as Gaumata, Monkey-Hanuman, Bar peepal as Bishnu-Shiva, etc. Hindus visiting Buddha Bihar/Gumba is a common principle in Nepal as well as in the world. However, the common world view in all communities is a better part of nature conservation.

\subsection{Role of Education for Culture and Nature Protection}

Education is one of the most important aspects of human society that can help to promote change in human behaviours and preserve the environment to maintain a harmonious relationship between culture and nature. An informant (teacher) said in school education there are contents about the preservation of biodiversity as well as environmental conservation. The Objective of the school curriculum is to develop and preserve the creativity of art and culture in their education. The environmental subject is also integrated into science subjects of grade XI and XII. The national educational policy also emphasizes nature conservation. A student also said that they were studying the subject matter of environment conservation. Likewise, university-level students are also studying for the environment. So, Nepali people seem to be aware of the hazards of environmental pollution and the importance of environmental conservation.

Government policy has promoted nature conservation through non-formal education too. Researchers asked the literate people of the villages whether they have got information about protecting resources. The informants informed that they (the member of the community forest group) have taken training/class conducted by the district forest office (Kaski). In probing question, they also have learned the way for resource protection from radio broadcasting and television programmes. From this report, it is clear that non-formal education also plays an important role in natural resource management.

Indigenous knowledge and practice of resource management can also play important role in the community. For example, Manmo community of China is conserving sacred community forests and valued by villagers mostly for their cultural significance. They believe in the forest by providing environmental services to the village and material benefits as well (Walter, 2004). Regarding this, an informant of the Gurung community said they are preserving their forest by their customary rule such as riti-thiti as worshiping the resources in the seasonal cycle. This system is transferring from generation to generation i.e., via informal education. Thus, practice and knowledge help to preserve nature.

As common information, in Nepali culture, people have plant bar-peepal on the resting place (chautari) with the belief of moksha (dharma) from ultimate life. They have been following this practice for years and thereby promoting greenery and biodiversity. This type of informal education is also playing a very important role in nature conservation. From analysis and interpretation of triangulating field report and different kinds of literature, it can be concluded Nepali culture and education is supporting nature conservation. Perhaps, these beliefs and practices of Nepal can play a role for a good example of the world for the protection of nature.

\section{Conclusion}

The research study was focused centrally on the relation between the natural world, the cultural world, and education. The study has explored the importance of nature and the effect of humans when nature is degraded. So, what role can be played by human culture to conserve nature? Certainly, there are human ethical knowledge and practice to conserve their mother earth. But, education also comes in the counterpart of them to conserve each other.

As the nature of the study area, the study was conducted adopting a qualitative research design. Field data were collected with the help of in-depth interviews using interview protocol. Participant observation was done with the help of an observation checklist. Informants' selection was done as the principle of purposive sampling. Data collection was completed with coding, analysing, and revisiting the informants. Data were collected from the ground knowledge of ethnic communities i.e., Brahmin, Gurung and Tamang. 
The study found that Gurungs and Tamangs with more or less common cultural knowledge and practice for nature conservation. As they are Bon followers (nature worshipers) both of them practice worshipping natural elements of their territory. They respect and believe in ancestral god and natural god in equal. So they conserve nature by adopting spiritual and materialistic ideas and practices. There is some difference in Brahmin culture because of the Hindu followers. They believe in different plants and animals in the form of different gods/goddesses. However, due to the acculturation, Hindus and non-Hindu culture have more or less common cultural knowledge and practice regarding nature conservation.

Education is found as an important factor to interlink nature and culture whether it is formal, informal, or non-formal. Education should not be oriented only towards human development (toward sophisticated life) i.e., homo-centrism but also to educate the people to value based on nature i.e., eco-centrism. This study concludes if those three factors are established in harmonized position there will be beauty, peace, and goodness for humans as well as all the creatures in the world.

This study is very important for environmental (nature) conservation in the global burning issue. It can promote understanding the interrelation of environment and human culture. But due some constrain as financial and time, the study is limited in the few ethnic communities (Brahmin, Gurung and Tamang) in Nepal. However, the study should be elaborated on a mass scale. As the nature of objectives, the study is limited in the qualitative method. The study also can be carried out through quantitative or mixed methods which can involve more informants and more communities of the world. This kind of study seems very few but due to its importance, the study should be increased its horizon. Hence all the academia, researchers, authentic persons, environmentalists should research in a multidisciplinary manner. Hence the following are the few areas for future research.

-Interrelation of nature and human culture in the world; in an educational perspective,

-Analysis of interrelation between nature and human culture,

-Environment conservation and sustainable development in a cultural perspective,

-Study of nature conservation in different community of Nepal.

\section{References}

Adhikari, J., \& Ghimire, S. (Eds.) (2003). Vatavaraniya Nyaya Srot sangalo (Nepali). Kathmandu, Nepal, Martin chautari \& Social development \& Research centre.

Aggarwal, J. C. (2002). Theory \& Principles of Education, Philosophical \& Sociological bases of education (12th ed.). New Delhi, Vikas Publishing house Pvt. Ltd.

Bhalla, P. P. (2007). Hindu Rites, Rituals, Customs, and Traditions. Delhi, Hindulogy books.

Bhattachan, K. B. (2008). Minorities and Indigenous Peoples of Nepal. Nepal, NCARD.

Creswell, J. W. (2012). Educational Research (4th ed.). USA, Pearson Education Inc.

Denzin, N. K., \& Lincoln, Y. S. (Eds.) (2005). The discipline \& practice of qualitative research. The Sage Handbook of Qualitative Research (3rd ed.). The U.K., Sage Publication, Inc.

Flick, U. (2010). An Introduction to qualitative research (4th ed.). India, Sage Publication Pvt Ltd.

Giddens, A. (2009). Sociology (6th ed.). UK, Polity Press.

Goucher, C., LeGuin, C., \& Walton, L. (1998). In the balance: Themes in world history. [Changing Environments, changing societies] Boston; McGraw-Hill. Retrieved from https://www.learner.org/cources/worldhistory/support/reading_4_1.pdf

Gurung, G. P. (2018). Educational Perspective of Indigenous Knowledge and Practice of Plant Management of Gurung Community. Ph.D. Thesis, Tribhuvan University, Nepal.

Gurung, O. P. (1996). Customary Systems of Natural Resource Management Among Tarami Magars of Western Nepal. PhD Thesis, Cornell University, New York.

Hay-Edie, T., \& Hadley, M. (1998). Natural sacred sites-A Comparative Approach to their cultural and Biological Significance. In P. S. Ramakrishnan, K. G. Saxena, \& U. M. Chandrashekara (Eds.), Conserving the sacred for Biodiversity Management (pp. 47-67). New Delhi, Oxford \& IBH publishing co. Pvt. Ltd.

Hesselink, F., \& Cerovsky, J. (n.d). Learning to change the future. A bird's-eye view of the history of IUCN Commission on education and Commission. IUCN (pp. 1-25). Retrieved from https://www.iucn.org/downloads/cec_history_annex_28sept08.pdf

Hughes, J. D., \& Chandran, M. D. S. (1998). Sacred Groves Around the Earth: An Overview. In P. S. Ramakrishnan (Ed.), Conserving the Sacred for Biodiversity Management (pp. 69-86). New Delhi, Oxford \& IBH publishing Co. Pvt. Ltd. 
Karki, U. B. (2000). Environmental Eduation. In B. D. Pande, S. D. Maharjan, B. Sakya, \& U. B. Karki (Eds.), Environmental Education Source book for Bachelor of Education Programme (pp. 20-40). Nepal, IUCN.

Khatri, N. K. (2005). Conservation of Biological Diversity (Plants and animals) in legal aspect of Nepal. $\mathrm{PhD}$ Thesis, Tribhuvan University, Nepal.

Konsa, K. (2016). Natural and cultural heritage framing meaning and practices. International journal of social sustainability, in economics, social and cultural context, 12(4), 9-18. https://doi.org/10.18848/2325-1115/CGP/v12i04/9-18

Lama, K. (2010). Traditional knowledge of the Tamang on forest management. In M. Rigal, \& G. B. Yongen Tamang (Eds.), Readings on Indigenous Culture and Knowledge (pp. 95-104). Nepal, Institute of Governance and Development.

Obomsawin, R. (1993). Indigenous knowledge and Sustainable Development. Paper presentation at the international symposium held at the international institute of rural reconstruction; Sep 20-26, 1992 and in Silang and Philippines 1993.

Patton, M. Q. (2002). Qualitative Research \& Evaluation Methods (3rd ed.). London, Sage Publication.

Pennmellen, S. B. (2014). An Anthropological study of a Japanese Tree-Burial: Environment, Kinship and death (pp. 177-201). Retrieved from https://www.researchgate.net/publication/320297098_An_Anthropological_Study_of_a_Japanese_Tree_Bu rial_Environment_Kinship_and_Death

Qinghua, W. (2004). Local environmental services: Forest Management \& Terraced Agriculture, A case study of Hani of the Ailao Mountains, Yunnan, China. In D. Nathan, G. Kelkar, \& P. Walter (Eds.), Globalization \& Indigenous Peoples in Asia (pp. 104-118). London, Sage publications. https://doi.org/10.4135/9788132101802.n4

Rainisio, N., \& Inghilleri, P. (2013). Culture, environmental psychology, and wellbeing: an emergent theoretical framework (pp. 103-116). https://doi.org/10.1007/978-94-007-4611-4_7

Saxena, K. G., Rao, K. S., \& Maikhuri, R. K. (1998). Religious and Cultural Perspective of Biodiversity Conservation in India: A review. In P. S. Ramakrishnan, K. G. Saxena, \& U. M. Chandrashekara (Eds.), Conserving the Sacred for Biodiversity Management (pp. 153-161). New Delhi, Oxford \& IBH Publishing Co. Pvt. Ltd.

Siwakoti, H. R. (2009). Indigenous Health and Healing System: Potentiality and Prospects for Education. MPhil Thesis, TU Faculty of Education.

Skanavis, C., \& Petreniti, V. (2006). Non formal Environmental Education: Centre of Environmental Education. Conference paper (pp.

Source:///c:/Users/Sanothimi\%20campus/oesktop/Nature-culture/SkanavisPetrenitiPRE2006.pdf

Stoffle, R.W., Toupal, R. S., \& Zedeno, M. N. (2003). Landscape, Nature and Culture: A diachronic model of human nature adaptations. In H. Selin (Ed.), Nature cross cultures: view of nature and environment in non western cultures (pp. 97-114). Netherlands: Kluwer Academic publishers. https://doi.org/10.1007/978-94-017-0149-5_5

Trochium, W. M. K. (n.d). Research Methods Knowledge base. Retrieved from https://www.socialbaseresearchmethods.net/kb/

UNESCO report. (2007). Links between biological and cultural diversity. Concepts, methods and experiences 26-28 Sep. 2007. Retrieved from https://unescodoc.unesco.org/ark:/48223/pdf0000159255

Walter, P. (2004). Tourism and forest management among the Hani in Xishuangbanna, China. In D. Nathan, G. Kelkar, \& P. Waller (Eds.), Globalization and Indigenous People in Asia (pp. 207-224). London, Sage Publishing. https://doi.org/10.4135/9788132101802.n9

Withange, H. (1998). Role of Sacred Groves in Conservation and Management of Biodiversity in Sri Lanka. In P. S. Ramakrishnan, K. G. Saxena, \& U. M. Chandrashekara (Eds.), Conserving the Sacred for Biodiversity Management (pp. 171-186). New Delhi, Oxford \& IBH Publishing Co. Pvt. Ltd.

\section{Copyrights}

Copyright for this article is retained by the author(s), with first publication rights granted to the journal.

This is an open-access article distributed under the terms and conditions of the Creative Commons Attribution license (http://creativecommons.org/licenses/by/4.0/). 